\title{
PARADIGMA ISLAMISASI ILMU DI INDONESIA PERSPEKTIF AMIN ABDULLAH
}

\author{
Kamaruzzaman \\ e-Mail : kamaruzz@yahoo.com \\ UIN Imam Bonjol Padang
}

\begin{abstract}
Abstrak : Tulisan ini bertujuan untuk mengetahui dan menjelaskan tentang pandangan Amin Abdullah terhadap dinamika keilmuan yang berkembang dewasa ini serta konsep integrasi ilmu Amin Abdullah dalam menanggulangi dikotomi ilmu yang telah berlangsung berabad-abad lamanya di dunia Islam khususnya di Indonesia. Dalam hal ini, Amin Abdullah berpendapat Islam harus diletakkan dalam dua dimensinya, yaitu normativitas dan historisitas tapi realitasnya aspek normatif dan historis kerap berjalan secara timpang. Umumnya pengajaran ilmu-ilmu agama Islam yang normatif-tekstual terlepas dari perkembangan ilmu pengetahuan dan tekhnologi, ilmu-ilmu sosial, ekonomi, hukum dan humaniora. Hubungan ilmu agama dan ilmu umum tidak harus mengambil posisi berhadap-hadapan dan bersifat dikhotomis
\end{abstract}

Kata Kunci : Integrasi ilmu, Amin Abdullah, Islamisasi Sains

\section{PENDAHULUAN}

Dalam sejarah Islam, kita mengenal nama-nama seperti AlMansur, Al-Ma'mun, dan Harun AlRasyid, yang memberikan perhatian teramat besar bagi perkembangan ilmu di dunia Islam. Pada masa pemerintahan Al-Mansur, misalnya, proses penerjemahan karya-karya filosof Yunani ke dalam bahasa Arab berjalan dengan pesat. Dikabarkan bahwa Al-Mansur telah memerintahkan penerjemahan naskah-naskah Yunani mengenai filsafat dan ilmu, dengan memberikan imbalan yang besar kepada para ahli bahasa (penerjemah). Pada masa Harun Al-Rasyid (786-809) proses penerjemahan itu juga masih terus berlangsung. Harun memerintahkan Yuhanna (Yahya) Ibn Masawayh (w. 857), seorang dokter Istana, untuk menerjemahkan bukubuku kuno mengenai kedokteran. Di masa itu juga diterjemahkan karyakarya dalam bidang astronomi, ${ }^{1}$

Hal ini dapat kita lihat pada alBiruni. Sebagai ilmuwan dan saintis Muslim, al-Biruni selalu meletakkan sains sebagai sarana untuk mengungkap rahasia alam. Hasil eksperimen dan penelitiannya selalu bermuara pada pengakuan keberadaan sang pencipta (Allah). Meskipun telah menghasilkan 180 karya dalam berbagai disiplin ilmu, ia selalu mengingatkan bahwa metode ilmiah yang dikembangkannya memiliki keterbatasan. Wahyu Allah satusatunya otoritas tertinggi yang mutlak. Karena itu, jika ia terbentur pada suatu masalah, ia pun segera mengembalikannya kepada Allah. Di sini al-Biruni berusaha menundukkan

\footnotetext{
${ }^{1}$ Amsal Bakhtiar, Filsafat Ilmu, ( Jakarta: PT Raja Grafindo Persada, 2011hlm. 40
} 
sains di bawah kerangka nilai-nilai iman. $^{2}$

Namun sejak abad ke-13 umat Islam melepaskan kegiatannya dalam pengembangan sains dan teknologi, penguasaan sains dan teknologi berpindah dari tangan umat Islam ke Eropa Barat, sebagai akibat pengalaman yang pahit memisahkan agama dari politik, ekonomi, dan ilmu pengetahuan. IPTEK dikembangkan dalam suasana yang sekular; kemampuan umat dalam bidang ini semakin merosot; usaha keras yang dilakukan Kesultanan Turki untuk mengejar Eropa Barat dengan mendorong teknologinya menemui kegagalan, karena tidak didukung oleh sains. Turki hanya mendapat teknologi yang cepat menjadi usang sedangkan Eropa Barat yang menguasai sains sumber teknologi, selalu memperoleh teknologi baru dari kegiatan sainsnya. ${ }^{3}$

Di masa Dinasti Saljuq berkuasa (429-700 H/1037-1299 M), pemisahan (dikotomi) ilmu sudah mulai dilakukan di lembaga-lembaga pendidikan yang dibangun oleh pemerintah, di antara istitusi pendidikan yang dominan di masa Dinasti Saljuq adalah madrasah Nizamiah. Pendirian madrasah Nizamiah pada masa itu tak terlepas dari kepentingan politik yang mengitarinya. Madrasah Nizamiah oleh Dinasti Saljuq dijadikan alat propaganda tandingan untuk menekan pengaruh aliran Syi'i dan untuk menyebarluaskan aliran Sunni di tengah - tengah masyarakat di seluruh

2 RA Gunadi, Dari Penakluk Jerussalem Hingga Angka Nol, (Jakarta: Republika, 2002) hlm. 66

${ }^{3}$ Achmad Baiquni, Al-Qur'an Ilmu Pengetahuan dan Teknologi, (Yogyakarta: PT Dana Bhakti Prima Yasa, 1995), hlm. 137-138 wilayah kekuasaan Dinasti Saljuq dengan cara memasukkan materi keagamaan versi Sunni ke dalam kurikulum madrasah Nizamiyah. Sedangkan ilmu - ilmu kealaman (fisika, kimia, astronomi) dan kedokteran tidak termasuk kedalam kurikulum pendidikan madrasah Nizamiyyah. Sekali lagi motif utama pendidikan Madrasah Nizamiyyah adalah politik dan ideologi. Ada kemungkinan, materi - materi di atas tidak dimasukkan ke dalam kurikulum di Madrasah Nizamiyyah karena memang tidak begitu diperlukan dalam kerangka kepentingan ideologi dan politik penguasa waktu itu. Sehingga cukup beralasan mengapa materi keagamaan mendominasi dalam kurikulum pendidikan madrasah Nizamiah pada saat itu. ${ }^{4}$

Mengakarnya paham dikotomi keilmuan amat berpengaruh pada dinamika umat Islam itu sendiri. Pada masa kejayaan Islam, hampir tidak terlihat adanya dikotomi keilmuan antara "ilmu-ilmu umum" dan "ilmuilmu keislaman". Perkembangan ilmu pengetahuan berjalan demikian pesatnya, meliputi ilmu agama, bahasa, sejarah, aljabar, fisika, kedokteran, dan lain-lain. Tokoh-tokoh seperti AlFarabi, Ibnu Sina, Ikhwan Al-Shafa menyadari bahwa kesempurnaan manusia hanya akan terwujud dengan penyerasian antara "ilmu-ilmu umum" dan "ilmu-ilmu keislaman", sebagai satu bagian yang tak terpisahkan dalam komponen keilmuan dalam Islam.

Di Indonesia masalah dikotomi antara ilmu umum dan agama sudah di mulai pada zaman penjajahan Belanda.

\footnotetext{
${ }^{4}$ Lihat Arif Budi Raharjo, Suwito dkk. Sejarah Sosial Pendidikan Islam, (Jakarta: Prenada Media, 2005), hlm 154.
} 
Terhadap pendidikan Islam, Belanda cendrung menghambat dan menghalangi karena dinilai sebagai salah satu faktor yang akan mengancam keberlangsungan pemerintah. Hambatan dan halangan yang dibuat oleh Belanda antara lain pemerintah dapat membubarkan sekolah-sekolah yang tidak mempunyai izin atau yang tak disukai yang disebut sebagai Wilde School Ordonantie atau Ordonasi Sekolah Liar. Di samping itu juga mengeluarkan ordinantie yang isinya melarang para guru, kyai atau ulama untuk mengajar jika tidak mempunyai izin. ${ }^{5}$

Pemerintah Belanda juga menerapkan prinsip konkordansi, yakni suatu prinsip yang memaksa sekolah berorientasi Barat dan menghalangi dalam penyesuaian pendidikan dengan kondisi di Indonesia. Dengan demikian setiap sekolah dipaksa menjadi agen kebudayaan Barat dan dijadikan sebagai alat untuk misionaris Kristen. Prinsip dan pola ini mereka tempuh karena mereka tidak ingin masyarakat pribumi menjadi pintar dan tidak ingin Islam menjadi maju. Karena jika masyarakatnya pintar dan Islam maju, terancamlah kekuasaan mereka, terancamlah keuntungan yang berlipat dalam bidang perdangangan mereka dan terancam pula misi mereka untuk menyebarkan bahkan mengkristenkan seluruh Indonesia, sebagaimana yang menjadi cita-cita Snouck Hurgronje. ${ }^{6}$

Akibat kesewenang-wenanganan Belanda itu timbullah rasa antipati terhadap apapun yang datang dari Belanda, termasuk dalam hal

\footnotetext{
${ }^{5}$ Abudin Nata, Kapita Selekta

Pendidikan Islam, (Bandung: Penerbit

Angkasa, 2003), hlm. 17

${ }^{6}$ Ibid., hlm. 20-21
}

pendidikan. Pondok pesantren sebagai lembaga pendidikan tertua di Indonesia mengembangkan metode pendidikannya sendiri-sendiri, dan menolak hal-hal yang berasal dari Belanda. metode belajar yang lazim pada masa itu menggunakan metode sorogan atau bondongan. Umumnya pesantren semacam ini " steril" dari ilmu pengetahuan umum. Pola ini disebut pondok salaf atau tradisional

Dalam catatan Nurcholish Madjid sebagaimana yang dikutip oleh Yasmardi didalam bukunya yang berjudul "Modernisasi Pesantren: Kritik Nurcholish Madjid Terhadap Pendidikan Islam Tradisional" setidaknya kitab-kitab klasik yang diajarkan di dalam pesantren mencakup cabang ilmu-ilmu; fiqh, tauhid, tasauf, dan nahwu-sharf. Atau dapat juga dikatakan konsentrasi keilmuan yang berkembang di pesantren pada umumnya mencakup tidak kurang dari 12 macam disiplin keilmuan; nahwu, sharf, balaqhah, tauhid, fiqh, ushul fiqh, qawaid fiqhiyah, tafsir, hadits, muthalah al-haditsah, tasauf, dan mantiq.

Akibat sepak terjang Belanda itu sampai sekarang fenomena dikotomi ilmu masih bisa kita lihat pada dunia pendidikan di Indonesia yakni adanya sekolah umum/Perguruan Tinggi umum dibawah naungan Departemen Pendidikan Nasional dan sekolah agama/Perguruan Tinggi agama dibawah naungan Departemen Agama. Di masyarakat kita ada istilah ilmu umum dan ilmu agama, guru umum dan guru agama. Bahkan Perguruan

\footnotetext{
${ }^{7}$ Yasmadi, Modernisasi Pesantren: Kritik Nurcholish Madjid Terhadap Pendidikan Islam Tradisional , ( Jakarta: Ciputat Press, 2002), hlm. 68
} 
Tinggi Agama Islam seperti IAIN juga menerapkan dikotomi ilmu. Di lembaga IAIN Sembilan puluh persen $(90 \%)$ materi pelajarannya adalah ilmu-ilmu agama.

Salah satu tokoh di Indonesia yang gigih mengangkat masalah dikotomi ilmu umum dan ilmu agama ini adalah Prof. Dr. M. Amin Abdullah seorang cendikiawan Islam di Indonesia. Amin Abdullah menyebutkan bahwa Islam harus diletakkan dalam dua dimensinya, yaitu normativitas dan historisitas. Aspek normativitas ditekankan pada ajaran wahyu yang berupa teks-teks keagamaan, sedangkan sisi historisitas terletak pada pemahaman dan bagaimana orang atau kelompok orang melakukan interpretasi terhadap aturan-aturan agama yang menjadi pilihannya yang kemudian menjadi aktivitas kesehariannya. Amin Abdullah berpendapat aspek normatif dan historis kerap berjalan secara timpang. Misalnya, pengajaran ilmuilmu agama Islam yang normatiftekstual terlepas dari perkembangan ilmu pengetahuan dan tekhnologi, ilmu-ilmu sosial, ekonomi, hukum dan humaniora. Menurut Amin Abdullah hubungan ilmu agama dan ilmu umum tidak harus mengambil posisi berhadap-hadapan dan bersifat dikhotomis. Ibarat sebuah koin (mata uang) dengan dua permukaan. Hubungan antara kedua permukaan koin tidak dapat dipisahkan, tetapi secara tegas dan jelas dapat dibedakan. ${ }^{8}$

Amin Abdullah melihat aktivitas pendidikan dan keilmuan di

\footnotetext{
8 Amin Abdullah, Studi Agama: Normativitas atau Historisitas, (Yogyakarta: Pustaka Pelajar, 2004), hlm. vii
}

Perguruan Tinggi Umum dan Perguruan Tinggi Agama di tanah air mirip-mirip seperti pola kerja keilmuan awal abad renaissance hingga era revolusi informasi, yang sekarang ini mulai diratapi oleh banyak kalangan. Hati nurani terlepas dari akal sehat. Nafsu serakah menguasai perilaku cerdik pandai. Praktik korupsi, kolusi dan nepotisme merajalela. Lingkungan alam rusak berat. Tindakan kekerasan dan mutual distrust (saling mencurigai dan rasa saling tidak percaya) mewabah dimana-mana. ${ }^{9}$

Amin Abdullah menegaskan di dalam bukunya yang berjudul Islamic Studies di Perguruan Tinggi: Pendekatan Integratif-Interkonektif, Amin Abdullah melukiskan pola hubungan antar disiplin keilmuan keagamaan dan keilmuan nonkeagamaan secara metaforis miripmirip dengan "jaring laba-laba keilmuan" (Spider web), dimana antar berbagai disiplin yang berbeda tersebut saling berhubungan dan berinteraksi secara aktif-dinamis. Yaitu, corak hubungan antar berbagai disiplin dan metode keilmuan tersebut bercorak integratif-interkonektif. ${ }^{10}$

Masing-masing disiplin ilmu masih tetap dapat menjaga identitas dan eksistensinya sendiri-sendiri, tetapi selalu terbuka ruang untuk berdialog, berkomunikasi dan berdiskusi dengan disiplin ilmu lain. tidak hanya dapat berdiskusi antar rumpun disiplin ilmu

9 Amin Abdullah dkk, Menyatukan Kembali Ilmu-Ilmu Agama dan Umum: Upaya Mempertemukan Epistemologi Islam dan Umum, (Yogyakarta: Sunan Kalijaga Press, 2003), hlm. 4

${ }^{10}$ Amin Abdullah, Islamic Studies di Perguruan Tinggi: Pendekatan IntegratifInterkonektif (Yogyakarta: Pustaka Pelajar, 2012), hlm. 107 
kealaman secara internal, namun juga mampu dan bersedia untuk berdiskusi dan menerima masukan dari keilmuan external, seperti dengan ilmu-ilmu sosial dan humaniora. Ilmu-ilmu agama atau yang lebih popular disebut dengan Ulumu al-din tidak terkecuali disini. Ia juga tidak dapat berdiri sendiri, terpisah, terisolasi dari hubungan dan kontak dengan keilmuan lain di luar dirinya. Ia harus terbuka dan membuka diri serta bersedia berdialog, berkomunikasi, menerima masukan, kritik dan bersinergi dengan keilmuan alam, keilmuan sosial dan humaniora. ${ }^{11}$

Lebih lanjut menurut Amin Abdullah yang pernah menjabat sebagai Rektor IAIN Sunan Kalijaga (sekarang menjadi UIN Kalijaga) selama dua periode (2001-2010), di era UIN, fakultas Syari'ah tidak boleh menolak untuk dimasuki mata kuliah baru yang mengandung muatan humanities kontemporer dan ilmu-ilmu sosial seperti hermeneutika, cultural dan religious studies, HAM , sensitivitas gender, filsafat ilmu dan begitu seterusnya. Jika tidak, maka mahasiswa akan menderita (suffer) ketika mereka keluar kampus dan berhadapan dengan realitas sosialkemasyarakatan dan realitas sosial keagamaan yang begitu kompleks. Begitu juga dengan fakultas Tarbiyah , Dakwah, Adab dan Ushuluddin.

\section{PEMBAHASAN}

Amin Abdullah men-Ilustrasikan gagasannya sama persis seperti skema pada jarring laba-laba berikut gagasannya terkait dengan konsep jaring laba-laba

Salah satu tokoh di Indonesia yang gigih mengangkat masalah dikotomi ilmu umum dan ilmu agama adalah Prof. Dr. M. Amin Abdullah. Amin Abdullah menyebutkan bahwa Islam harus diletakkan dalam dua dimensinya, yaitu normativitas dan historisitas. Aspek normativitas ditekankan pada ajaran wahyu yang berupa teks-teks keagamaan, sedangkan sisi historisitas terletak pada pemahaman dan bagaimana orang atau kelompok orang melakukan interpretasi terhadap aturanaturan agama yang menjadi pilihannya yang kemudian menjadi aktivitas kesehariannya. $^{12}$

Amin Abdullah berpendapat aspek normatif dan historis kerap berjalan secara timpang. Umumnya pengajaran ilmu-ilmu agama Islam yang normatif-tekstual terlepas dari perkembangan ilmu pengetahuan dan tekhnologi, ilmu-ilmu sosial, ekonomi, hukum dan humaniora. Menurut Amin Abdullah hubungan ilmu agama dan ilmu umum tidak harus mengambil posisi berhadaphadapan dan bersifat dikhotomis. Ibarat sebuah koin (mata uang) dengan dua permukaan. Hubungan antara kedua permukaan koin tidak dapat

12 Amin Abdullah, Studi Agama: Normativitas atau Historisitas, (Yogyakarta: Pustaka Pelajar, 2004), hlm. vii 
dipisahkan, tetapi secara tegas dan jelas dapat dibedakan. ${ }^{13}$

Amin Abdullah menegaskan dalam bukunya yang berjudul Islamic Studies di Perguruan Tinggi: Pendekatan Integratif-Interkonektif, Amin Abdullah melukiskan pola hubungan antar disiplin keilmuan keagamaan dan keilmuan nonkeagamaan secara metaforis miripmirip dengan "jaring laba-laba keilmuan" (Spider web), dimana antar berbagai disiplin yang berbeda tersebut saling berhubungan dan berinteraksi secara aktif-dinamis. corak hubungan antar berbagai disiplin dan metode keilmuan tersebut bercorak integratifinterkonektif. $^{14}$ Jargon integratifinterkonektif memang cukup populer di dengar terutama bagi kalangan civitas akademika UIN Sunan Kalijaga Yogyakarta. Jargon ini tidak hanya sekedar jargon pasca peralihan IAIN menjadi UIN tetapi lebih dari itu menjadi core values dan paradigma yang akan dikembangkan UIN Sunan Kalijaga yang mengisyaratkan tidak ada lagi dikotomi antara ilmu agama dan ilmu umum.

Menurut Amin Abdullah studi Islam integrasi-interkoneksi adalah kajian tentang ilmu-ilmu keislaman, baik objek bahasan maupun orientasi metodologinya dan mengkaji salah satu bidang keilmuan dengan memanfaatkan bidang keilmuan lainnya serta melihat kesaling-terkaitan antar berbagai disiplin ilmu tersebut untuk mempertemukan ilmu-ilmu

\footnotetext{
${ }^{13}$ Ibid

14 Amin Abdullah, dkk. Islamic Studies: Dalam Paradigma IntegrasiInterkoneksi (Sebuah Antologi). (Penerbit SUKA Press.2007). hlm.107
}

agama (khususnya Islam) dengan ilmuilmu umum. Tujuan dari IntegrasiInterkoneksi adalah memahami kehidupan manusia yang kompleks secara terpadu dan menyeluruh. Harapan dari Integrasi-Interkoneksi ini terwujudnya manusia yang mulia (QS Al-Mujadilah: 11) manusia yang berderajat tinggi, yakni manusia yang beriman,berilmu dan beramal shaleh.

Pendekatan integratifinterkonektif merupakan pendekatan yang tidak akan saling melumatkan dan peleburan antara keilmuan umum dan agama. Pendekatan integratifinterkonektif adalah pendekatan yang berusaha saling menghargai; keilmuan umum dan agama sadar akan keterbatasan masing-masing dalam memecahkan persoalan manusia. Hal ini akan melahirkan sebuah kerja sama, setidaknya saling memahami pendekatan (approach) dan metode berpikir (process dan procedure) antar kedua keilmuan tersebut. Pendekatan integratif-integkonektif merupakan usaha untuk menjadikan sebuah keterhubungan antara keilmuan agama dan keilmuan umum yang tergabung dalam ilmu alam, ilmu sosial dan humaniora. ${ }^{15}$

Masing-masing disiplin ilmu masih tetap dapat menjaga identitas dan eksistensinya sendiri-sendiri, tetapi selalu terbuka ruang untuk berdialog, berkomunikasi dan berdiskusi dengan disiplin ilmu lain. tidak hanya dapat berdiskusi antar rumpun disiplin ilmu kealaman secara internal, namun juga mampu dan bersedia untuk berdiskusi dan menerima masukan dari keilmuan external, seperti dengan ilmu-ilmu

\footnotetext{
${ }^{15}$ Ibid, hlm. 53.
} 
sosial dan humaniora. Ilmu-ilmu agama atau yang lebih popular disebut dengan Ulumu al-din tidak terkecuali disini. Ia juga tidak dapat berdiri sendiri, terpisah, terisolasi dari hubungan dan kontak dengan keilmuan lain di luar dirinya. Ia harus terbuka dan membuka diri serta bersedia berdialog, berkomunikasi, menerima masukan, kritik dan bersinergi dengan keilmuan alam, keilmuan sosial dan humaniora. ${ }^{16}$

Dalam pandangan Amin Abdullah, integrasi keilmuan memiliki kesulitan, yaitu kesulitan memadukan studi Islam dan umum yang kadang tidak saling akur karena keduanya ingin saling mengalahkan. Oleh karena itu di perlukan usaha interkoneksitas yang lebih arif dan bijaksana. Interkoneksitas menurut Amin Abdullah adalah usaha memahami kompleksitas fenomena kehidupan yang dihadapi dan dijalani manusia, sehingga setiap bangunan keilmuan apapun, baik keilmuan agama (Islam, Kristen, Budha dll) keilmuan sosial, humaniora, maupun kealaman tidak dapat berdiri sendiri, maka dibutuhkan kerja sama, saling tegur sapa, saling membutuhkan, saling koreksi dan saling keterhubungan antara disiplin keilmuan. ${ }^{17}$

Amin Abdullah mengartikan Integrasi sebagai "berlawanan dengan pemisahan", yaitu usaha memadukan ilmu umum dan ilmu agama. ${ }^{18}$ Model dari integrasi adalah "Menjadikan Al-

\footnotetext{
${ }^{16}$ Amin Abdullah, Agama, Ilmu dan Budaya: Paradigma integrasi-interkoneksi keilmuan (Yogyakarta, 17 Agustus 2013), hlm. 11

${ }^{17}$ Amin Abdullah, dkk, op.cit., hlm. 5152

${ }^{18}$ Ibid, hlm. 49
}

Quran dan sunnah sebagai grand theory pengetahuan. Sehingga ayatayat qualiyah dan kauniyah dapat dipakai." Perbedaan yang mendasar antara islamisasi ilmu dengan integrasi ilmu adalah dalam hal pelumatan keilmuan umum dan agama. Dalam islamisasi ilmu, keilmuan Islam akan memilih dan memilah ilmu-ilmu yang dianggap islami dan ilmu yang bukan islami dengan menghilangkan ilmuilmu yang bukan islami atau tidak cocok dengan Islam. Sedangkan integrasi dalam hal ini berkaitan usaha memadukan keilmuan umum dan Islam tanpa harus menghilangkan keunikankeunikan antara dua keilmuan tersebut. $^{19}$

Lebih lanjut menurut Amin Abdullah era UIN, fakultas Syari'ah tidak boleh menolak untuk dimasuki mata kuliah baru yang mengandung muatan humanities kontemporer dan ilmu-ilmu sosial seperti hermeneutika, cultural dan religious studies, HAM, sensitivitas gender, filsafat ilmu dan begitu seterusnya. Jika tidak, maka mahasiswa akan menderita (suffer) ketika mereka keluar kampus dan berhadapan dengan realitas sosialkemasyarakatan dan realitas sosial keagamaan yang begitu kompleks. Begitu juga fakultas Tarbiyah , Dakwah, Adab, Ushuluddin.

Amin Abdullah menciptakan Spider Theory/Thariqah al-'Ankabut (Teori Jaring Laba-Laba) dalam pengembangan pemikiran akademik Islamic Studies di perguruan tinggi,. Gambar dibawah ini di rancang oleh Amin Abdullah mengilustrasikan hubungan jaring laba-laba keilmuan

\footnotetext{
${ }^{19} \mathrm{Ibid}, \mathrm{hlm} .50$
} 
yang bercorak teoantroposentrisintegralistik.

\section{"JARING LABA-LABA KEILMUAN TEOANTROPOSENTRIS INTEGRALISTIK"}

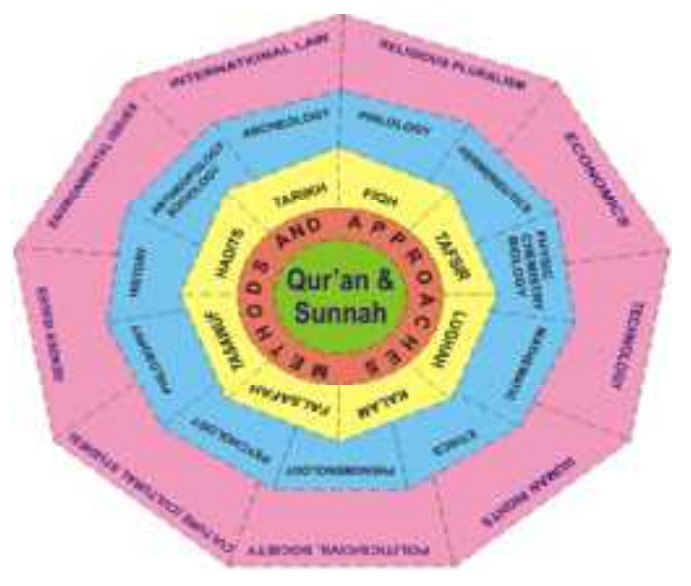

Pada jaring laba-laba tersebut, tergambar disitu bahwa jarak pandang dan horizon keilmuan integralistik begitu luas (tidak myopic). Garis putus-putus pada gambar di atas menunjukkan ruang kosong di setiap bidang keilmuan yang memungkinkan dimasuki bidang keilmuan yang lain. saling berdialog dan bertegur sapa. Terdapat wilayah pusat yaitu Qur'an dan sunnah sebagai core keilmuan yang berada di titik sentral. Bagian selanjutnya adalah berbagai macam pendekatan dan metodologi. Metodologi dan pendekatan tersebut digunakan untuk menafsirkan alQur'an dan sunnah yang dimaknai secara baru (hermeneutis). Pada bagian selanjutnya terdapat ilmu-ilmu umum yang merupakan pengembangan lebih lanjut dari ilmu agama. Selanjutnya, untuk menghubungkan agar ilmu umum dan ilmu agama relevan diterapkan sesuai perkembangan zaman, maka ilmu-ilmu tersebut dikoneksikan dengan berbagai issueissue yang sedang berkembang. Issueissue yang berangkat dari perkembangan kondisi sosio kultural tersebut menempati lapisan terluar. Core keilmuan berupa al-Qur'an dan Sunnah yang menempati titik sentral jaring laba-laba ini disebut juga hadlaratun-nash, ilmu agama dan ilmu umum disebut hadlaratul-ilmi, dan keilmuan kontemporer yang didasarkan kondisi perkembangan zaman disebut hadlaratul-falsafah.

Hadarah al-nash (budaya agama yang semata-mata mengacu pada teks) dalam kombinasinya dengan hadarah al-ilm (sain dan teknologi), tanpa mengenal humanities komtemporer sedikutpun juga berbahaya, karena jika tidak hati-hati akan mudah terbawa arus ke arah gerakan radicalismfundamentalism. Hadarah al-nash, (penyangga budaya teks bayani), memang tidak lagi bisa berdiri sendiri, terlepas sama sekali dari hadarahal-ilm (teknik, komunikasi) dan juga tidak bisa terlepas dari hadarah al-falsafah (etik) dan begitu sebaliknya. Hadarah al-ilm (budaya ilmu), yaitu ilmu-ilmu empiris yang menghasilkan sain dan teknologi, akan tidak punya "karakter", yang berpihak pada kehidupan manusia dan lingkungan hidup, jika tidak dipandu oleh Hadarah al-falsafah (budaya etik-emansipatoris) yang kokoh. Begitu juga, hadarah alfalsafah (budaya filsafat) akan terasa kering, jika tidak terkait dengan isu-isu keagamaan yang termuat dalam budaya teks dan lebih-lebih jika menjauh dari problem-problem yang ditimbulkan dan dihadapi oleh hadarah al-ilm (budaya ilmu-ilmu empiris-teknis). ${ }^{20}$

\footnotetext{
${ }^{20}$ Ibid, hlm. 402-403
} 
Dikuasainya dengan baik keilmuan tersebut diharapkan lahirnya sosok manusia beragama (Islam) yang terampil dalam menangani dan menganalisis isu-isu yang menyentuh problem kemanusiaan dan keagamaan era modern dan pasca modern. Sekaligus terampil dalam kehidupan sektor tradisional maupun modern lantaran dikuasainya salah satu ilmu dasar dan keterampilan yang dapat menopang kehidupan era informasiglobalisasi. Di atas segalanya, dalam setiap langkah yang ditempuh, selalu dibarengi landasan etika-moral keagamaan yang objektif dan kokoh, karena keberadaan Al-Qur'an dan alSunnah yang dimaknai secara baru (hermeneutis) selalu menjadi landasan pijak pandangan hidup keagamaan manusia yang menyatu dalam satu tarikan nafas keilmuan dan keagamaan. Kesemuanya diabdikan untuk kesejahteraan manusia secara bersamasama tanpa pandang latar belakang etnisitas, agama, ras maupun golongan. ${ }^{21}$

Kondisi sekarang ini, aktivitas keilmuan di Perguruan Tinggi Agama, khususnya IAIN dan STAIN di seluruh tanah air hanya terfokus dan terbatas pada lingkar 1 dan jalur lingkar lapis 2 (Kalam, Falsafah, Tasawuf, Hadits, Tarikh, Fiqh, Tafsir, Lughah). Itupun boleh disebut hanya terbatas pada ruang gerak pendekatan keilmuan humaniora klasik. IAIN pada umumnya belum mampu memasuki diskusi ilmu-ilmu sosial dan humanities kontemporer seperti tergambar pada jalur lingkar 2

${ }^{21}$ Amin Abdullah, Islamic Studies di Perguruan Tinggi, Pendekatan Integratif Interkonektif (Yogyakarta: Pustaka Pelajar, 2012), hlm. 106
(Antropologi, Sosiologi, Psikologi, Filsafat dengan berbagai pendekatan yang ditawarkannya). Akibatnya, terjadi jurang wawasan keislaman yang tidak terjembatani antara ilmu-ilmu keislaman klasik dan ilmu-ilmu keislaman baru yang telah memanfaatkan analisis ilmu-ilmu sosial dan humaniora kontemporer, bahkan juga ilmu-ilmu alam ${ }^{22}$.

Upaya-upaya untuk menjembatani jurang wawasan tersebut dilakukan oleh Program Strata 2 (Magister) tetapi tidak semua IAIN dapat melakukannya, Keterbatasan sumber daya tenaga pengajar yang memahami dan menguasai ilmu-ilmu keislaman sekaligus ilmu-ilmu sosial dan humanities kontemporer. Amin Abdullah menambahkan yang dapat melakukan pun, akan menemui banyak kesulitan karena selain keterbatasan sumber daya manusia, juga mind set mahasiswa strata 1 sudah sedemikian kental warna studi teks klasiknormatif tanpa tersentuh oleh wawasan Iptek, ilmu sosial maupun humaniora. Isu-isu sosial, politik, ekonomi, keagamaan, militer, gender lingkungan, ilmu-ilmu sosial dan humanities kontemporer pasca modern, seperti yang tergambar pada jalur lingkar lapis 3 hampir-hampir tidak tersentuh oleh kajian keislaman ditanah air khususnya di IAIN.

Amin Abdullah mencontohkan ilmu yang bercorak integralistik, yaitu ilmu Ekonomi Syariah, yang sudah nyata ada praktik penyatuan antara wahyu Tuhan dan temuan pikiran manusia. Ada BMI (Bank Muamalat), Bank BNI Syariah, usaha-usaha

\footnotetext{
${ }^{22}$ Ibid, hlm. 108
} 
agrobisnis, transportasi, kelautan, dan sebagainya. Agama menyediakan etika dalam perilaku ekonomi di antaranya adalah bagi hasil (al-mudharabah), dan kerja sama (al-musyarakah). Disitu terjadi proses objektifikasi dari etika agama menjadi ilmu agama yang dapat bermanfaat bagi orang dari semua penganut agama, non agama, atau bahkan anti-agama. Dengan basis moralitas keagamaan yang humanistik ini dituntut dapat memasuki wilayahwilayah yang lebih luas seperti psikologi, sosiologi, antropologi, social work, lingkungan, kesehatan, teknologi, ekonomi, politik, hubungan internasional, hukum dan peradilan dan begitu seterusnya. $^{23}$

\section{DAMPAK DIKOTOMI MENURUT AMIN ABDULLAH}

ILMU

Amin Abdullah berpendapat latar belakang krisis energi hingga moral dan prilaku manusia yang tidak sebagaimana mestinya akibat pola pendidikan yang kurang tepat. Amin Abdullah melihat aktivitas pendidikan dan keilmuan di Perguruan Tinggi Umum dan Perguruan Tinggi Agama di tanah air mirip-mirip seperti pola kerja keilmuan awal abad renaissance hingga era revolusi informasi, yang sekarang ini mulai diratapi oleh banyak kalangan. Pendidikan dikembangkan dengan dikotomi, yakni memisahkan antara ilmu-ilmu agama dan ilmu-ilmu umum. Hati nurani terlepas dari akal sehat. Nafsu serakah menguasai perilaku cerdik pandai. Praktik korupsi, kolusi dan nepotisme merajalela. Lingkungan alam rusak berat. Tindakan kekerasan dan mutual distrust (saling mencurigai dan rasa

\footnotetext{
${ }^{23}$ Ibid, hlm 104-105.
}

saling tidak percaya) mewabah dimana-mana. ${ }^{24}$

Hingga kini masih kuat anggapan dalam masyarakat luas yang mengatakan bahwa " agama" dan "ilmu" adalah dua entitas yang tidak bisa dipertemukan. Keduanya mempunyai wilayah sendiri-sendiri, terpisah antara satu dan lainnya, baik dari segi objek formal-material, metode ilmuwan maupun status teori masingmasing bahkan sampai ke institusi penyelenggaraanya. Dengan lain ungkapan, ilmu tidak mempedulikan agama dan agama tidak mempedulikan ilmu. Akibatnya, manusia terpinggirkan dari kandungan nilai spiritualitasmoralitas dan terasing dari aspek-aspek kehidupan yang menopang kehidupannya. Begitulah sebuah gambaran praktik kependidikan dan aktivitas keilmuan di tanah air sekarang ini dengan berbagai dampak negatif yang ditimbulkan dan dirasakan oleh masyarakat luas. Oleh karenanya, anggapan yang tidak tepat tersebut perlu dikoreksi dan diluruskan. ${ }^{25}$

Paradigma keilmuan yang dibangun IAIN masih bercorak normatif, teologis transendental sehingga perlu dibarengi oleh pendekatan keilmuan yang bersifat empiris, partikular, verifikatif yang menjadi basis keilmuan umum. Tujuannya adalah kesimpulan yang objektif, komprehensif, tidak parsial apalagi berbau ideologis. Tuntutan keilmuan saat ini dan masa yang akan datang bukan lagi mengusung sekian

24 Amin Abdullah dkk, Menyatukan Kembali Ilmu-Ilmu Agama dan Umum: Upaya Mempertemukan Epistemologi Islam dan Umum, (Yogyakarta: Sunan Kalijaga Press, 2003), hlm. 4

${ }^{25}$ Amin Abdullah, Islamic Studies..op.cit, hlm 92-93. 
banyak pandapat para ulama masa lalu namun menuntut adanya kreatifitas untuk menerjemahkan pemahaman masa lalu ke dalam konteks kekinian dengan mengikuti perkembangan zaman. Keterbelahan keilmuan yang ada di IAIN dengan mengandalkan keilmuan ulumuddin (dasar-dasar ilmu agama) saja sangat tidak memadai untuk menyikapi persoalan kemanusiaan yang terus berkembang. Studi Islam tidak mungkin lagi mengembangkan sikap monodisiplin tanpa bertegur sapa, berinteraksi, berdialog dengan keilmuan diluar dirinya.

Keilmuan yanga ada di IAIN tidak saling berdialog satu sama lain apalagi menjalin kontak dan komunikasi dengan keilmuan umum sehingga tidak menyadari akan keterkaitan satu keilmuan dengan keilmuan lainnya. Pengembangan keilmuan yang ada hanya berjalan sendiri-sendiri. Keterpisahan keduanya berakibat pada rendahnya mutu pendidikan dan kemunduran dunia Islam pada umumnya. Dampak negatif dari kenyataan ini tidak terlalu menyenangkan. Dikotomi Ilmu umumIlmu agama, hegemoni bidang ilmu tertentu terhadap bidang lainnya, superior-inferior feeling dari masingmasing bidang ilmu, hirarki ilmu utama-ilmu komplementer, adalah akibat-akibat laten yang harus ditanggung dari kenyataan diatas. Tidak jarang muncul konflik di ranah sosial maupun politik akibat adanya ekslusifisme dari masing-masing bidang ilmu. Satu keilmuan menafikan, menyalahkan, memarginalkan keilmuan lainnya. Sebagai contoh dalam daratan ilmu-ilmu keislaman sering terjadi "takdir" (pengkafiran) antara sesama muslim hanya karena disiplin keilmuannya berbeda.

Menurut Amin Abdullah kesenjangan wawasan keilmuan ini cukup berakibat pada dinamika kehidupan sosial keagamaan dalam masyarakat Indonesia mengingat alumni IAIN banyak yang menjadi tokoh di masyarakat dimanapun mereka berada. Dengan demikian sangat penting untuk melakukan kajian ulang terhadap struktur fundamental keilmuan Islam dan membangun kultur akademik yang lebih dinamis. $^{26}$

Amin Abdullah menyebutkan perbedaan ini semakin hari semakin jauh ibarat deret ukur terbalik dan membawa akibat yang tidak nyaman bagi kehidupan dan kesejahteraan umat manusia. Pola pikir yang serba bipolardikotomis ini menjadikan manusia terasing dari nilai-nilai spiritualitasmoralitas, terasing dari dirinya sendiri, terasing dari keluarga dan masyarakat sekelilingnya, terasing dari lingkungan alam dan ragam hayati yang menopang kehidupannya serta terasing dari denyut nadi lingkungan sosial-budaya sekitarnya. Singkatnya, terjadi proses dehumanisasi secara massif baik pada tataran kehidupan keilmuan maupun keagamaan. $^{27}$

Amin Abdullah menyebutkan dalam ketiga revolusi peradaban manusia, yaitu revolusi hijau, revolusi industri dan revolusi informasi, tidak ada satu pun ilmuawan Muslim tercatat namanya dalam lembaran tinta emas pengembang ilmu pengetahuan.

${ }^{26}$ Widia Fithtri, dkk. Konversi IAIN Imam Bonjol Menuju UIN “ Analisis Struktur Fundamental Keilmuan Islam Ditijau Dari Perspektif Filsafat". (Pusat Penelitian IAIN Imam Bonjol Padang, 2012). hlm 1-2.

${ }^{27}$ Ibid, hlm 93-94. 
Perkembangan dan pertumbuhan ilmuilmu sekular sebagai simbol keberhasilan Perguruan Tinggi Umum yang tercabut dari nilai-nilai akar moral dan etik kehidupan manusia disatu pihak, sementara dilain pihak, perkembangan dan pertumbuhan Perguruan Tinggi Agama (baca : Islam) yang hanya menekankan ilmu-ilmu keagamaan dan teks-teks keislaman normatif era klasik yang berdampak pada persoalan penciptaan tenaga kerja terampil dalam dunia ketenagakerjaan, menjadikan kedua-duanya mengalami proses pertumbuhan yang tidak sehat serta membawa dampak negatif bagi pertumbuhan dan perkembangan kehidupan sosial-budaya, sosialekonomi, sosial-politik, dan sosialkeagamaan di tanah air. ${ }^{28}$

Amin Abdullah menegaskan secara psikologis banyak orang mengalami kegelisahan luar biasa karena antara dunia yang dia alami, yang multi-dimensi, dengan keilmuan yang dihayati, yang hanya satu dimensi dan yang satu-satunya dia pahami, ternyata tidak sejalan. Orang yang menghayati ilmu fiqih saja pasti gelisah ketika berhadapan dengan kenyataan sosial yang berbeda dengan isi ilmunya. Orang yang menhayati ilmu ekonomi saja pasti gelisah ketika berhadapan dengan "logika zakat dan sedekah" ala fiqih. Orang yang menghayati ilmu geografi saja pasti gelisah ketika berhadapan dengan adanya ruang baru yang disebut "dunia virtual" atau "dunia maya". 29

Dari sini tergambar bahwa ilmuilmu sekular yang dikembangkan di Perguruan Tinggi Umum dan ilmuilmu agama yang dikembangkan di

\footnotetext{
${ }^{28} \mathrm{Ibid}, \mathrm{hlm}$ 5-6

${ }^{29} \mathrm{Ibid}$, hlm. vii-viii
}

Perguruan Tinggi Agama secara terpisah, yang sekarang ini berjalan, sedang terjangkit krisis relevansi (tidak dapat memecahkan banyak persoalan), mengalami kemandekan dan kebuntuan (tertutup untuk pencarian alternatifalternatif yang lebih mensejahterakan manusia) dan penuh bias-bias kepentingan (keagamaan, ras, etnis, filosofis, ekonomis, politik, gender, peradaban). Dari latar belakang seperti itulah, gerakan rapprochment (kesediaan untuk saling menerima keberadaan yang lain dengan lapang dada) antara dua kubu keilmuan merupakan suatu keniscayaan. Gerakan rapprochment, dapat juga disebut sebagai gerakan penyatuan atau reintegrasi epistemologi keilmuan adalah suatu keniscayaan dan mutlak diperlukan untuk mengantisipasi perkembangan-perkembangan yang serba kompleks dan tak terduga pada milenium ketiga serta tanggung jawab kemanusiaan bersama secara global dalam mengelola sumber daya alam yang serta terbatas dan sumber daya manusia Indonesia yang berkualitas sebagai khalifatu Allah fi-al-ardh. ${ }^{30}$

Memang semua kerusakan ini tidak dapat dibebankan atau dikembalikan kepada dunia pendidikan. Perguruan Tinggi Agama khususnya IAIN, sacara sadar harus berani mengkaji ulang visi, misi dan paradigma keilmuan yang pernah dibangunnya selama 50 tahun. Begitu juga Perguruan-Perguruan Tinggi Umum yang sudah mapan dan berjalan selama ini. Ide dan usulan perlunya dikembangkan Ilmu-ilmu Sosial Profetik dan kajian agama secara

${ }^{30}$ Abdullah, M. Amin, "Islamic Studies Di Perguruan Tinggi Pendekatan IntegratifInterkonektif”. Yogyakarta: Pustaka Pelajar, 2012. hlm 97. 
kontekstual di Perguruan Tinggi Umum seperti Universitas Gajah Mada adalah merupakan tanda adanya keprihatinan yang serius tentang arah pengambangan dan tujuan pembelajaran ilmu-ilmu umum pada Perguruan Tinggi Umum yang telah berjalan selama 50 tahun belakangan ini. $^{31}$

Bangunan ilmu pengetahuan yang dikotomik antara ilmu pengetahuan umum dan ilmu pengetahuan agama harus diubah menjadi bangunan keilmuan baru yang lebih holistik-integralistik atau paling tidak bersifat komplementer. Tujuan IAIN perlu diorientasikan pada lahirnya serjana yang memiliki kemampuan sekaligus, yaitu kemampuan menganalisis secara akademis, kemampuan melakukan inovasi dan kemampuan memimpin sesuai dengan tuntunan persoalan kemasyarakatan, keilmuan, maupun profesi yang ditekuninya dalam satu tarikan nafas etos keilmuan dan keagamaan.

\section{RELEVANSI INTEGRASI KEILMUAN AMIN ABDULLAH BAGI KEILMUAN ISLAM DI INDONESIA}

Problem di IAIN dan di Perguruan Tinggi Agama pada umumnya adalah Keterbelahan keilmuan yang mengandalkan keilmuan ulumuddin (dasar-dasar ilmu agama) saja dan pengembangan keilmuan yang hanya berjalan sendirisendiri. Contohnya mata kuliah Filsafat Ilmu tidak merata di ajarkan di semua Fakultas yang ada di IAIN. Keilmuan yang ada antar Fakultas di IAIN saja tidak saling berdialog satu sama lain apalagi menjalin kontak dan komunikasi sehingga tidak jarang terjadi sesama mahasiswa saling membanggakan Fakultasnya masing-masing bahkan dikenal adanya istilah Fakultas favorit dan Fakultas buangan. Hal ini tentu saja tidak memberikan pengaruh yang baik.

Keilmuan yang banyak mengandalkan ilmu agama saja dan membatasi keilmuan umum yang saat ini terus berjalan di IAIN tidak memadai untuk menyikapi persoalan kemanusiaan yang terus berkembang. Studi Islam tidak mungkin lagi mengembangkan sikap monodisiplin tanpa bertegur sapa, berinteraksi, berdialog dengan keilmuan diluar dirinya. Pemikiran inilah yang mendorong adanya gagasan tentang pengembangan IAIN (khususnya Jakarta dan Yogyakarta) sebagai pilot project menjadi Universitas Islam Negeri (UIN), yang lalu di ikuti oleh kampus IAIN yang lain seperti IAIN Alaudin Makassar yang telah menjadi UIN dan yang terbaru adalah IAIN Sumatra Utara Medan dan IAIN Raden Fattah Palembang yang keduanya telah resmi berubah status menjadi UIN. IAIN Imam Bonjol Padang sendiri tengah berjuang untuk menjadi UIN.

Pengembangan dan konversi IAIN ke UIN adalah proyek keilmuan. Proyek pengembangan wawasan keilmuan dan perubahan tata pikir keilmuan yang bernafaskan keagamaan transformatif. Bukan berubah asal berubah, bukan sekedar ikut-ikutan, bukan pula sekedar proyek fisik. Konversi dari IAIN ke UIN adalah momentum untuk membenahi dan menyembuhkan "luka-luka dikotomi" keilmuan umum dan agama yang

\footnotetext{
${ }^{31}$, Ibid, hlm. 97-98
} 
makin hari makin menyakitkan. ${ }^{32}$ Studi Islam yang di kembangkan di UIN tidak hanya terbatas pada keilmuan yang selama ini dipahami dan dikembangkan di lingkungan IAIN secara umum, yakni al-ulum alnaqliyah saja, namun juga al-'ulum al'aqliyah yang selama ini banyak dikaji di lembaga-lembaga pendidikan umum yang dianggap sekuler.

Perubahan dan perkembangan ini bukan sekedar asal berkembang dan berubah. Diperlukan konsep yang matang dan detail, sehingga tidak mengulangi eksperimen dan pengalaman sejarah yang dilakukan oleh perguruan-perguruan tinggi umum dan agama yang didirikan oleh negara maupun swasta. Perkembangan ini berasal dalam kerangka dan semangat harmonisasi keilmuan dan keagamaan, bukannya keterpisahan antara keduanya meskipun ada dibawah satu atap kampus. Program reintegrasi epistemologi keilmuan dan implikasinya dalam proses belajar mengajar secara akademik pada gilirannya akan menghilangkan dikotomi antara ilmu-ilmu umum dan ilmu-ilmu agama seperti yang telah berjalan selama ini. Hal ini penting untuk memberikan landasan moral Islam terhadap perkembangan ilmu pengetahuan dan teknologi, lingkungan hidup, sosial-ekonomi, dan sosialbudaya, sosial-politik, dan sosialkeagamaan di tanah air, sekaligus mengartikulasikan ajaran Islam sesuai dengan perkembangan dan kemajuan teknologi, humaniora dan sosial kontemporer. ${ }^{33}$

Di UIN mencakup bukan hanya fakultas-fakultas Agama, tetapi juga

\footnotetext{
${ }^{32}$ Amin Abdullah, dkk., Menyatukan..., Op.cit hlm. 33.

${ }^{33}$ Ibid, hlm. 100.
}

fakultas-fakultas umum dengan corak epistemology keilmuan dan etika moral keagamaan yang integralistik. Dalam konsep ini, fakultas-fakultas agama tetap dipertahankan seperti yang ada sekarang, namun perlu dikembangkan kurikulumnya yang sesuai dengan kebutuhan masyarakat pengguna jasa IAIN di era global dan diperkuat tenaga pengajar dan dosen-dosennya dengan berbagai metode dan pendekatan baru dalam Islamic Studies, humanities, dan ilmu-ilmu sosial, sedangkan dalam fakultas-fakultas umum - baik dalam bentuk wider mandate (perintah lebih luas) maupun universal - perlu dibekali muatanmuatan spritualitas dan moral keagamaan yang lebih kritis dan terarah dalam format integrated curriculum, dan bukannya separated curriculum (kurikulum menyendiri) seperti yang berjalan selama ini. ${ }^{34}$

Amin Abdullah berpendapat proyek besar reintegrasi epistemologi keilmuan umum dan agama mengandung arti perlunya dialog dan kerja sama antara disiplin ilmu umum dan agama yang lebih erat di masa yang akan datang. Pendekatan interdisciplinary dikedepankan, interkoneksitas dan sensitivitas antar berbagai disiplin ilmu perlu memperoleh skala prioritas dan perlu dibangun dan dikembangkan terus menerus tanpa kenal henti. Interkoneksitas dan sensitifitas antara berbagai disiplin ilmu-ilmu kealaman dengan disiplin ilmu-ilmu sosial dan disiplin humanities serta disiplin ilmuilmu agama perlu diupayakan secara terus menerus. Bukan eranya sekarang disiplin ilmu agama (Islam) menyendiri dan steril dari kontak dan intervensi

\footnotetext{
${ }^{34}$ Ibid, hlm. 99-100
} 
ilmu-ilmu sosial, humaniora dan ilmuilmu kealaman. ${ }^{35}$

Lebih lanjut Amin Abdullah menegaskan para pimpinan fakultas, ketua jurusan, pimpinan program studi dan dosen pada umumnya harus berani berfikir ke depan untuk mempersiapkan kebutuhan generasi ilmuan dan praktisi sosial-agama yang akan datang (nex genera-tion), bukan sekedar mempertahankan status quo yang dicapai sekarang. ${ }^{36}$ Yang layak dipertimbangkan ke depan untuk mendesign mata kuliah, kurikulum dan silabi UIN adalah dengan cara menghindari pitfall dan jebakanjebakan keangkuhan disiplin ilmu yang merasa "pasti" dalam wilayah sendirisendiri tanpa mengenal masukan dari disiplin di luar dirinya. ${ }^{37}$

Kurikulum yang akan diterapkan di PTAI harus menggunakan pendekatan integratif interkonektif yaitu pendekatan yang menempatkan wilayah agama dan sains, serta antar ilmu saling menyapa satu dengan yang lainnya sehingga menjadi satu bangunan utuh. Tidak ada dikotomi sains dan agama. Begitu juga tidak ada dikotomi antara ilmu-ilmu qauliyah/hadarah al-nash (ilmu-ilmu yang berkaitan dengan teks keagamaan) dengan ilmu-ilmu kauniyah ijtima'iyyah/hadarah al-ilm (ilmu-ilmu kealamaan dan kemasyarakatan) maupun hadarah alfalsafah (ilmu-ilmu etika kefilsafatan). Wilayah keilmuan tersebut tidak dikaji secara parsial melainkan dikaji secara integratif dan interkonektif atau saling berhubungan satu dengan lainnya.

\footnotetext{
${ }^{35}$ Ibid hlm. 33

36 Amin Abdullah, dkk., Islamic Studies: Dalam Paradigm..., op.cit., hlm. 36

${ }^{37}$ Ibid, hlm. 36-37
}

Di masa depan alumni UIN perlu mempunyai kualifikasi tertentu, yang berbeda dari universitas lain. Setidaknya, jika ada alumni UIN akan berprofesi sebagai guru, hakim, da'i atau pekerja sosial, konsultan dan begitu seterusnya mereka tidaknya harus terkurung dalam sangkar isolated profession (profesi yang steril dan terpisah dari persoalan masyarakat sekitarnya), tetapi lebih dituntut untuk sekaligus sebagai penggagas dan pelopor social empowerment dan social agent of change dengan muatan etik yang memihak rakyat kecil yang tidak berdaya (mustadl'afun) dan lingkungan hidup yang sehat. ${ }^{38}$

Amin Abdullah menyebutkan sudah saatnya para calon pendidik selain memiliki wawasan pengetahuan agama yang dalam sebagai basisnya, juga mampu menguasai ilmu-ilmu sosial-humaniora sebagai tantangan sekaligus problem solving dalam kehidupan masyarakat modern. Para calon pendidik seharusnya tidak hanya mampu menguasai situasi kelas atau sekolah, akan tetapi juga diharapkan mampu mengatasi problematika aktual di masyarakat seperti gender, HAM, civil society, korupsi, kolusi, nepotisme, pendidikan karakter, pendidikan multikultural, pluralism. Para pendidik hendaknya menjadi problem solver baik di lingkungan sekolah dan sosialkemasyarakatan. $^{39}$

Paradigma baru yang dibangun oleh Amin Abdullah dengan integratif-

\begin{tabular}{llr}
\hline \multicolumn{3}{c}{${ }^{38}$ Ibid, hlm. 34-35. } \\
${ }^{39}$ Didik Harianto (2010). Studi Islam \\
Integrasi & Interkoneksi. http & ://didik \\
harianto & Studi $\quad$ Islam & Integrasi \\
Interkoneksi.htm . di unduh 20 April 2014
\end{tabular}


interkonektif ini memang sangat relevan dengan kebutuhan zaman saat ini. Koneksitas ini diharapkan mampu menjawab kebuntuan dalam keilmuan Islam dan lebih jauh lagi dapat menjawab kompleksitas problem kemanusiaan di era globalisasi. Paradigma integratifinterkonektif yang ditawarkan oleh Amin Abdullah ini merupakan jawaban dari berbagai persoalan diatas. Integrasi dan interkoneksi antar berbagai disiplin ilmu, baik dari keilmuan sekuler maupun keilmuan agama, akan menjadikan keduanya saling terkait satu sama lain, "bertegur sapa", saling mengisi kekurangan dan kelebihan satu sama lain. Dengan demikian maka ilmu agama (baca ilmu keislaman) tidak lagi hanya berkutat pada teks-teks klasik tetapi juga menyentuh pada ilmu-ilmu sosial kontemporer.

Dengan paradigma ini juga, maka tiga wilayah pokok dalam ilmu pengetahuan, yakni natural sciences, social sciences dan humanities tidak lagi berdiri sendiri tetapi akan saling terkait satu dengan lainnya. Ketiganya juga akan menjadi semakin cair meski tidak akan menyatukan ketiganya, tetapi paling tidak akan ada lagi superioritas dan inferioritas dalam keilmuan, tidak ada lagi klaim kebenaran ilmu pengetahuan sehingga dengan paradigma ini para ilmuwan yang menekuni keilmuan ini juga akan mempunya sikap dan cara berfikir yang berbeda dari sebelumnya.

Bukankah ini merupakan catatan sejarah panjang yang hendak diukir umat Islam setelah tertinggal oleh dua peristiwa penting dalam sejarah peradaban dunia, yaitu era Revolusi Hijau dan era Revolusi Industri. Akankah sekarang umat Islam juga tertinggal juga oleh Revolusi Informasi? Tantangan di era globalisasi menuntut respon tepat dan cepat dalam sisitem pendidikan Islam secara keseluruhan. Jika kaum Muslimin tidak hanya ingin sekedar survive ditengah persaingan global yang semakin tajam dan ketat, tetapi juga berharap mampu tampil di depan, maka re-orientasi pemikiran mengenai pendidikan Islam dan rekonstruksi sistem dan kelembagaan merupakan keniscayaan.

Umat Islam tidak boleh berpangku tangan dan menonton dari luar seluruh perkembangan yang terjadi. Jika umat Islam utamanya para penyelenggara pendidikannya tidak segera mengambil langkah strategis ke depan terhadap paradigma keilmuan yang dimiliki sekarang ini dan memberi tawaran-tawaran baru untuk menyongsong perjalanan yang masih jauh ke depan, kapan lagi dimulai. ${ }^{40}$

\section{DAFTAR KEPUSTAKAAN}

Abdullah, M.Amin, Kata Pengantar
dalam Peters dan Gaymon
Bennet Menjembatani Sains dan Agama Jakarta: Gunung Mulia, 2004 , dkk. Islamic Studies: Dalam Paradigma IntegrasiInterkoneksi (Sebuah Antologi). Penerbit SUKA Press.2007 , Studi Agama: Normativitas atau Historisitas, Yogyakarta: Pustaka Pelajar, 2011 , Agama, Ilmu dan Budaya: Paradigma integrasi-

${ }^{40}$ Amin Abdullah, Islamic Studies di Perguruan..., Op.cit., hlm. 99 
interkoneksi keilmuan,

Yogyakarta, 17 Agustus 2013 , dkk, Menyatukan Kembali Ilmu-Ilmu Agama dan Umum: Upaya Mempertemukan Epistemologi Islam dan Umum, Yogyakarta: Sunan Kalijaga Press, 2003

, Islamic Studies di Perguruan

Tinggi: Pendekatan IntegratifInterkonektif , Yogyakarta: Pustaka Pelajar, 2012

Agus, Bustanuddi, Integrasi Sains dan Agama.Jakarta : UI-Press, 2013

Al-Albani, Muhammad Nashiruddin, Shahih Sunan Ibnu Majab I, Jakarta: Pustaka Azzam,2007

Al-Hanif, Achmad Fahrizal Zulfani: Http/// Prof.Dr.H.M. Amin Abdullah, MA/ Pecinta Biografi Habaib Dan Ulama. Html

Arikunto, Suharsimi, Manajemen Penelitian, Jakarta: Rineka Cipta, 2009

Anton, Beker dan A Zubeir, metodologi penelitian filsafat, Yogyakarta: Kanisius, 1989

Baiquni, Achmad, Al-Qur'an Ilmu Pengetahuan dan Teknologi, Yogyakarta: PT Dana Bhakti Prima Yasa, 1995

Bakhtiar, Amsal, Filsafat Ilmu, Jakarta: PT Raja Grafindo Persada, 2011

Depdikbud, Kamus Besar Bahasa Indonesia, Jakarta: Balai Pustaka, 1993

Departemen Pendidikan, Kamus Besar Bahasa Indonesia, Jakarta: Balai Pustaka, 1998

Echols, Jhon M., dan Hassan Shadily, Kamus Inggris Indonesia, Jakarta: PT Gramedia, 2007

Fitri, Widia, dkk , Konversi IAIN Imam Bonjol menuju UIN: Analisis Struktur Fundamental Keilmuan
Islam ditinjau dari Perspektif Filsafat Ilmu, Padang, Pusat Penelitian IAIN IB, 2012

Gunadi, RA, Dari Penakluk Jerussalem Hingga Angka Nol, Jakarta: Republika, 2002

Harianto, Didik (2010). Studi Islam Integrasi Interkoneksi.http ://didik harianto Studi Islam Integrasi Interkoneksi.htm.

M.

Baihaqi.

A

"http://aicis.iainmataram.ac.id/b erita-dari-bedah-buku-biografiintelektual-m-aminabdullah.html"

Nata, Abudin, dkk, Integrasi Ilmu Agama dan Ilmu Umum, Jakarta: PT RajaGrafindo Persada, 2005 , Kapita Selekta Pendidikan

Islam, Bandung: Penerbit Angkasa, 2003

RA Gunadi, Dari Penakluk Jerussalem Hingga Angka Nol, Jakarta: Republika, 2002

Raharjo, Arif Budi, Suwito dkk. Sejarah Sosial Pendidikan Islam, Jakarta: Prenada Media, 2005

Ridwan, M. Deden, Tradisi Baru Penelitian Agama Islam: Tinjauan antar Disiplin Ilmu. Bandung : Penerbit Nuansa, 2001

Shihab, M. Quraish, Tafsir AlMishbah, Jakarta: Lentera Hati,2007

Steenbrink, Karel A.. Pesantren Madrasah Sekolah: Pendidikan Islam dalam Kurun Modern, (Jakarta: PT. Pustaka LP3ES Indonesia, 1994

Suprayogo, Imam dan Rasmianto, Perubahan Pendidikan Tinggi Islam: Rekleksi Perubahan IAIN/STAIN Menjadi UIN, 
18 Jurnal Al-Aqidah, Volume 10, Edisi 1, Juni 2018

Malang: UIN-Malang Press, Tradisional , Jakarta: Ciputat 2008

Press, 2002

Suriasumantri, Jujun S., Ilmu dalam Perspektif, Jakarta : Yayasan Obor Indonesia, 1999

Tim Perumus Fakultas Teknik UMJ, Al-Islam dan Iptek I, Jakarta: PT Raja Grafindo Persada,1998

Yasmadi, Modernisasi Pesantren: Kritik Nurcholish Madjid Terhadap Pendidikan Islam Yu'timaalahuyatazakka, Prof. Dr. HM. Amin Abdullah; Pemikiran, Kiprah dan Perjuangannya, dalam www.Wikipedia.com

Yasmadi, Modernisasi Pesantren: Kritik Nurcholish Madjid Terhadap Pendidikan Islam Tradisional , Jakarta: Ciputat Press, 2002 